\title{
Effect of Slag Composition on the Dissolution of Phosphorus from Steelmaking Slag by Selective Leaching
}

\author{
Chuan-ming $\mathrm{DU}^{11}{ }^{1 *} \mathrm{Xu} \mathrm{GAO}^{2)}$ Shigeru UEDA ${ }^{2)}$ and Shin-ya KITAMURA ${ }^{2)}$ \\ 1) Graduate School of Engineering, Tohoku University, 2-1-1 Katahira, Aoba-ku, Sendai, 980-8577 Japan. \\ 2) Institute of Multidisciplinary Research for Advanced Materials, Tohoku University, 2-1-1 Katahira, Aoba-ku, Sendai, 980- \\ 8577 Japan.
}

(Received on April 2, 2018; accepted on May 21, 2018)

\begin{abstract}
Steelmaking slag is considered a potential source of $\mathrm{P}$ because of its huge production. In steelmaking slag, $\mathrm{P}$ is mainly distributed in the $\mathrm{C}_{2} \mathrm{~S}-\mathrm{C}_{3} \mathrm{P}$ solid solution which is more water-soluble than other phases. In order to recover $P$ and recycle steelmaking slag, we have proposed the selective leaching of the P-concentrated solid solution. To clarify the applicability of this process to steelmaking slags with various compositions, the effects of $\mathrm{P}_{2} \mathrm{O}_{5}$ content, $\mathrm{Fe}_{2} \mathrm{O}_{3}$ content, and slag basicity on the dissolution behavior of the slag modified with the addition of $\mathrm{Na}_{2} \mathrm{O}$ were investigated in this study. It was determined that the dissolution ratio of $\mathrm{P}$ reached approximately $76 \%$ regardless of the $\mathrm{P}_{2} \mathrm{O}_{5}$ content in slag, while the dissolution of $\mathrm{Fe}$ and $\mathrm{Mg}$ was poor. In the case of high $\mathrm{P}_{2} \mathrm{O}_{5}$ content, a leachate with higher $\mathrm{P}$ concentration and lower $\mathrm{Ca}$ and $\mathrm{Si}$ concentrations was obtained, exhibiting excellent selective leaching of P. Increasing the $\mathrm{Fe}_{2} \mathrm{O}_{3}$ content in slag not only promoted the dissolution of $\mathrm{P}$ but also decreased the dissolution ratios of other elements. With the increase in slag basicity, the dissolution ratios of $\mathrm{Ca}$, $\mathrm{Si}$, and $\mathrm{P}$ all increased. Most of the solid solution was dissolved from each slag without a large dissolution of other phases at $\mathrm{pH} \mathrm{6,}$ indicating that selective leaching of the solid solution was achieved over a wide range of slag compositions. After leaching, a residue with low $\mathrm{P}_{2} \mathrm{O}_{5}$ content and high $\mathrm{Fe}_{2} \mathrm{O}_{3}$ content was obtained.
\end{abstract}

KEY WORDS: steelmaking slag; slag composition; dephosphorization; selective leaching; P recovery.

\section{Introduction}

The recycling of industrial by-product has attracted widespread attention because of resource exhaustion and environmental protection. Steelmaking slag, a major by-product of the steelmaking process, is produced in an enormous quantity annually. Although steelmaking slag contains many valuable components, such as $\mathrm{Fe}_{\mathrm{t}} \mathrm{O}, \mathrm{MnO}$, and $\mathrm{P}_{2} \mathrm{O}_{5}$, it is mainly used as a roadbed and civil engineering material. ${ }^{1)}$ The value of these elements in slag has not been exploited well. It would be desirable to recycle the steelmaking slag inside the ironmaking and steelmaking process, and to recover some valuable elements. However, the presence of $\mathrm{P}_{2} \mathrm{O}_{5}$ restricts the recycling of steelmaking slag, because it will result in high phosphorus $(\mathrm{P})$ content in hot metal and increase dephosphorization burden. Therefore, a method for efficient separation and removal of $\mathrm{P}_{2} \mathrm{O}_{5}$ from slag would facilitate its utilization. Although $\mathrm{P}$ is a detrimental impurity in steel, it is an essential element in fertilizer, and plays a significant role in agriculture. Because the supply of phosphate ores is currently becoming very tight, and Japan has no domestic phosphate resources, the P separated from steelmaking slag is considered a potential sustainable source of phosphate. ${ }^{2}$

\footnotetext{
* Corresponding author: E-mail: dcm198812@gmail.com DOI: http://dx.doi.org/10.2355/isijinternational.ISIJINT-2018-240
}

Steelmaking slag, especially dephosphorization slag, is generally within the $\mathrm{CaO}-\mathrm{SiO}_{2}-\mathrm{Fe}_{\mathrm{t}} \mathrm{O}-\mathrm{P}_{2} \mathrm{O}_{5}$ system, and after solidification, it mainly consists of calcium ferrite, wustite, and dicalcium silicate. The majority of the $\mathrm{P}_{2} \mathrm{O}_{5}$ in slag is distributed in the dicalcium silicate in the form of $2 \mathrm{CaO} \cdot \mathrm{SiO}_{2}-3 \mathrm{CaO} \cdot \mathrm{P}_{2} \mathrm{O}_{5}\left(\mathrm{C}_{2} \mathrm{~S}-\mathrm{C}_{3} \mathrm{P}\right)$ solid solution. ${ }^{3)}$ On the basis of the difference in properties between the $\mathrm{P}_{2} \mathrm{O}_{5}$ or $\mathrm{P}$-concentrated phase and other components, a great deal of effort has been made to recover P from slag by physical or chemical separation. A summary of the major technologies is presented in Table 1. Selective leaching of $\mathrm{P}$ is based on the fact that the P-concentrated solid solution dissolves more readily into the aqueous solution at a constant $\mathrm{pH}$ than do the other phases; ${ }^{9)}$ after leaching, the leachate containing soluble $\mathrm{P}$ can be used to produce phosphate fertilizer via precipitation. Because it is energy-saving and similar to the production of phosphate fertilizer via hydrometallurgical treatment, ${ }^{11)}$ selective leaching shows an advantage in the recovery of $\mathrm{P}$ from steelmaking slag compared with other methods. However, in past work, the dissolution ratio of $\mathrm{P}$ from steelmaking slag was not high. ${ }^{12)}$ To promote the dissolution of $\mathrm{P}$ and achieve selective leaching of the solid solution, a series of improvements and innovations were adopted in our previous studies. ${ }^{13-15)}$ It has been shown that a better selective leaching of $\mathrm{P}$ could be realized when a slag with high $\mathrm{P}_{2} \mathrm{O}_{5}$ content was modified by the addition of $\mathrm{Na}_{2} \mathrm{O}$, cooled slowly, and leached in a citric acid 
Table 1. Proposed technology to separate and recover P from steelmaking slag.

\begin{tabular}{|c|c|c|}
\hline Method & Researchers & Process Summary \\
\hline Floatation separation & Ono et al. ${ }^{4)}$ & Slag was separated into two layers by floatation of dicalcium silicate with low density. \\
\hline $\begin{array}{l}\text { Reduction of } \\
\text { dephosphorization } \\
\text { slag }\end{array}$ & $\begin{array}{l}\text { Li and Suito, }{ }^{5)} \\
\text { Ishikawa } \text { et al. }{ }^{6}\end{array}$ & $\begin{array}{l}\text { Dephosphorization slag was reduced by hot metal in a regenerator; the reduced P in hot metal was further } \\
\text { dephosphorized to produce fertilizer. }\end{array}$ \\
\hline $\begin{array}{l}\text { Magnetic } \\
\text { separation }\end{array}$ & $\begin{array}{l}\text { Yokoyama and } \\
\text { Nagasaka et al. }{ }^{7}\end{array}$ & $\mathrm{C}_{2} \mathrm{~S}-\mathrm{C}_{3} \mathrm{P}$ solid solution was separated from $\mathrm{Fe}_{\mathrm{t}} \mathrm{O}$-containing matrix phase with the aid of a magnetic field. \\
\hline Capillary action & Miki et al. ${ }^{8)}$ & $\begin{array}{l}\text { The FeO-rich liquid phase was drawn into sintered } \mathrm{CaO} \text { by capillary action, separating it from } \mathrm{C}_{2} \mathrm{~S}-\mathrm{C}_{3} \mathrm{P} \\
\text { solid solution. }\end{array}$ \\
\hline $\begin{array}{l}\text { Selective } \\
\text { leaching of P }\end{array}$ & $\begin{array}{l}\text { Teratoko and } \\
\text { Kitamura et al. } .^{9}\end{array}$ & In steelmaking slag, $\mathrm{C}_{2} \mathrm{~S}-\mathrm{C}_{3} \mathrm{P}$ solid solution was selectively dissolved in acid solution at a constant $\mathrm{pH}$. \\
\hline Super gravity & $\mathrm{Li}$ and Guo et al. ${ }^{10)}$ & Super gravity was applied to separate $\mathrm{C}_{2} \mathrm{~S}-\mathrm{C}_{3} \mathrm{P}$ solid solution from slag based on density difference. \\
\hline
\end{tabular}

$\left(\mathrm{H}_{3} \mathrm{C}_{6} \mathrm{H}_{5} \mathrm{O}_{7}\right)$ solution at $\mathrm{pH} 6$.

To clarify the applicability of selective leaching of $\mathrm{P}$ to steelmaking slags with various compositions, it is necessary to study the influence of slag composition on the dissolution behavior of $\mathrm{P}$ under the above-mentioned conditions. It is well known that the $\mathrm{Fe}_{\mathrm{t}} \mathrm{O}$ content and slag basicity $\left(\mathrm{R}=(\operatorname{mass} \% \mathrm{CaO}) /\left(\operatorname{mass} \% \mathrm{SiO}_{2}\right)\right)$ have a significant influence on the dephosphorization of hot metal; the $\mathrm{P}_{2} \mathrm{O}_{5}$ content in dephosphorization slag is gradually increasing with the deterioration in the quality of iron ores and the improvement in dephosphorization. ${ }^{16)}$ Consequently, in this study, the effects of $\mathrm{P}_{2} \mathrm{O}_{5}$ content, $\mathrm{Fe}_{2} \mathrm{O}_{3}$ content, and slag basicity on the dissolution behavior of the slag modified with the addition of $\mathrm{Na}_{2} \mathrm{O}$ were investigated.

\section{Experimental Method}

The experimental method is almost the same as that described in the previous papers. ${ }^{13-15)}$ Table 2 lists the compositions of slags used in this study. Because the slag containing $\mathrm{Fe}_{2} \mathrm{O}_{3}$ exhibited a higher dissolution ratio of $\left.\mathrm{P},{ }^{9}\right)$ $\mathrm{Fe}_{2} \mathrm{O}_{3}$ was used as the iron oxide in these slags. For Slags A-D, the $\mathrm{P}_{2} \mathrm{O}_{5}$ content varied from 3.0 to 10.0 mass $\%$. The effect of $\mathrm{Fe}_{2} \mathrm{O}_{3}$ content was investigated in the case of slags with 3.0 mass $\%$ of $\mathrm{P}_{2} \mathrm{O}_{5}$. When the effect of slag basicity was studied, the existence of $\mathrm{MnO}$ and $\mathrm{Al}_{2} \mathrm{O}_{3}$ was taken into consideration, and the $\mathrm{P}_{2} \mathrm{O}_{5}$ content was set as 7.0 mass $\%$. Synthetic slag was prepared by mixing reagent-grade $\mathrm{CaO}$ (obtained by the calcination of $\mathrm{CaCO}_{3}$ at $1273 \mathrm{~K}$ ), $\mathrm{SiO}_{2}$, $\mathrm{Fe}_{2} \mathrm{O}_{3}, \mathrm{Ca}_{3}\left(\mathrm{PO}_{4}\right), \mathrm{MgO}, \mathrm{MnO}, \mathrm{Al}_{2} \mathrm{O}_{3}$, and $\mathrm{Na}_{2} \mathrm{SiO}_{3}$, and then heating in an electric resistance furnace to $1823 \mathrm{~K}$ under air atmosphere. After holding at this temperature for $1 \mathrm{~h}$, the molten slag in a Pt crucible was first cooled to $1623 \mathrm{~K}$ and kept at this temperature for $20 \mathrm{~min}$ to precipitate solid solution. Finally, the slag was cooled to $1323 \mathrm{~K}$ at a speed of $5 \mathrm{~K} / \mathrm{min}$ until it was taken out of the furnace.

Following slag synthesis, leaching experiments were carried out in a Teflon container, which was placed in an isothermal water bath at $298 \mathrm{~K}$. The schematic of leaching apparatus is shown in Fig. 1. As mentioned in a previous study, ${ }^{15)} 1 \mathrm{~g}$ of the ground slag (with particles smaller than $53 \mu \mathrm{m}$ ) was added to $400 \mathrm{ml}$ of distilled water and stirred with an agitation speed of $200 \mathrm{rpm}$; to maintain a constant $\mathrm{pH}$ during leaching, the leaching agent (citric acid,
Table 2. Compositions of slags with different $\mathrm{P}_{2} \mathrm{O}_{5}, \mathrm{Fe}_{2} \mathrm{O}_{3}$ contents, and basicities (R) (mass\%).

\begin{tabular}{ccccccccc}
\hline Sample & $\mathrm{CaO}_{2}$ & $\mathrm{SiO}_{2}$ & $\mathrm{Fe}_{2} \mathrm{O}_{3}$ & $\mathrm{P}_{2} \mathrm{O}_{5}$ & $\mathrm{MgO}$ & $\mathrm{Na}_{2} \mathrm{O}$ & $\mathrm{MnO}$ & $\mathrm{Al}_{2} \mathrm{O}_{3}$ \\
\hline Slag A & 36.5 & 22.7 & 30.6 & 3.0 & 3.2 & 4.0 & - & - \\
Slag B & 35.5 & 22.1 & 29.8 & 5.5 & 3.1 & 4.0 & - & - \\
Slag C & 34.5 & 21.5 & 29.0 & 8.0 & 3.0 & 4.0 & - & - \\
Slag D & 33.7 & 21.0 & 28.3 & 10.0 & 2.9 & 4.0 & - & - \\
\hline Slag E & 40.3 & 25.1 & 24.0 & 3.0 & 3.5 & 4.0 & - & - \\
Slag F & 33.3 & 20.8 & 36.0 & 3.0 & 2.9 & 4.0 & - & - \\
\hline $\begin{array}{c}\text { Slag G } \\
(\mathrm{R}=1.4)\end{array}$ & 31.3 & 22.2 & 28.0 & 7.0 & 4.0 & 3.5 & 3.0 & 1.0 \\
$\begin{array}{c}\text { Slag H } \\
(\mathrm{R}=1.7)\end{array}$ & 33.7 & 19.8 & 28.0 & 7.0 & 4.0 & 3.5 & 3.0 & 1.0 \\
$\begin{array}{c}\text { Slag I } \\
(\mathrm{R}=2.0)\end{array}$ & 35.7 & 17.8 & 28.0 & 7.0 & 4.0 & 3.5 & 3.0 & 1.0 \\
\hline
\end{tabular}

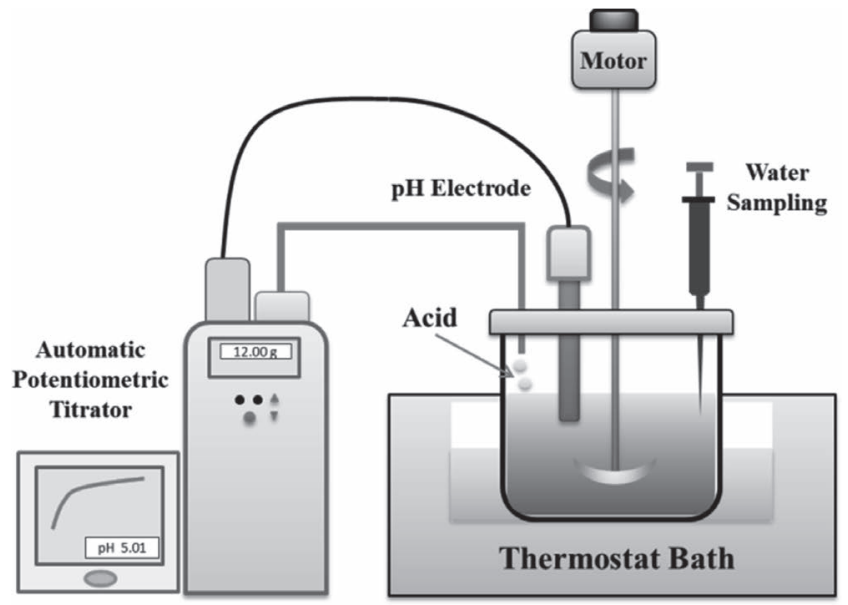

Fig. 1. Schematic of leaching apparatus.

$0.1 \mathrm{~mol} / \mathrm{L}$ ) was automatically added to the aqueous solution using a PC control system. Because the optimum $\mathrm{pH}$ for selective leaching of $\mathrm{P}$ was determined as 6 in a previous study, ${ }^{17)}$ each slag was leached at $\mathrm{pH} 6$, respectively, in this study. The aqueous solution was sampled at adequate intervals during leaching and filtered by a syringe filter $(<0.45$ $\mu \mathrm{m})$. The slurry was filtered to collect residue after $120 \mathrm{~min}$. The concentrations of each element in the aqueous solution 
were determined using inductively coupled plasma atomic emission spectroscopy (ICP-AES). The mineralogical compositions of each slag and their residues after leaching were analyzed by electron probe microanalysis (EPMA) and $\mathrm{X}$-ray diffraction (XRD) analysis.

\section{Results}

\subsection{Mineralogical Composition}

Figure 2 shows micrographs of the typical slags observed by EPMA. The chemical compositions of each phase in slags with different $\mathrm{P}_{2} \mathrm{O}_{5}$ and $\mathrm{Fe}_{2} \mathrm{O}_{3}$ contents, and basicity are listed in Tables 3 and 4. In each slag, three domains corresponding to three phases were clearly identified. The white-color phase with high $\mathrm{Fe}_{2} \mathrm{O}_{3}$ and $\mathrm{MgO}$ contents was magnesioferrite; the grey-color phase was considered the matrix phase because it mainly consisted of the $\mathrm{CaO}-\mathrm{SiO}_{2}-$ $\mathrm{Fe}_{2} \mathrm{O}_{3}$ system; the black-color phase rich in $\mathrm{P}_{2} \mathrm{O}_{5}$ was the solid solution. With the increase in the $\mathrm{P}_{2} \mathrm{O}_{5}$ content in slag, the $\mathrm{P}_{2} \mathrm{O}_{5}$ content in the solid solution and in the matrix phase both increased. Increasing the $\mathrm{Fe}_{2} \mathrm{O}_{3}$ content in slag also resulted in a higher $\mathrm{P}_{2} \mathrm{O}_{5}$ content in the solid solution. These results were in good agreement with the results reported by Shimauchi et al. ${ }^{18)}$ In regard to $\mathrm{Na}_{2} \mathrm{O}$, it was mainly distributed in the solid solution and matrix phase; a higher $\mathrm{P}_{2} \mathrm{O}_{5}$ content in the solid solution matched with a higher $\mathrm{Na}_{2} \mathrm{O}$ content in it. For the slags with different basicities, the $\mathrm{P}_{2} \mathrm{O}_{5}$ content in the solid solution and in the matrix phase both decreased with the increase in slag basicity; the $\mathrm{Na}_{2} \mathrm{O}$ content in the solid solution was almost the same. The composition of magnesioferrite had no dependence on the $\mathrm{P}_{2} \mathrm{O}_{5}$ and $\mathrm{Fe}_{2} \mathrm{O}_{3}$ contents, or slag basicity.

The distribution ratios of $\mathrm{P}_{2} \mathrm{O}_{5}$ and $\mathrm{Na}_{2} \mathrm{O}$ between solid solution and matrix phase were calculated as follows:

$$
L_{\mathrm{P} 2 \mathrm{O} 5}=\frac{\left(\% \mathrm{P}_{2} \mathrm{O}_{5}\right)_{S S}}{\left(\% \mathrm{P}_{2} \mathrm{O}_{5}\right)_{\text {Matrix }}}
$$

Table 3. Compositions of each phase in slags with various $\mathrm{P}_{2} \mathrm{O}_{5}$ and $\mathrm{Fe}_{2} \mathrm{O}_{3}$ contents (mass\%).

\begin{tabular}{|c|c|c|c|c|c|c|c|}
\hline & & $\mathrm{CaO}$ & $\mathrm{SiO}_{2}$ & $\mathrm{Fe}_{2} \mathrm{O}_{3}$ & $\mathrm{P}_{2} \mathrm{O}_{5}$ & $\mathrm{MgO}$ & $\mathrm{Na}_{2} \mathrm{O}$ \\
\hline \multirow{4}{*}{$\begin{array}{l}\text { Magnesio- } \\
\text { ferrite }\end{array}$} & Slag A $\left(3.0 \% \mathrm{P}_{2} \mathrm{O}_{5}\right)$ & 2.3 & 0.0 & 86.1 & 0.0 & 10.4 & 1.2 \\
\hline & Slag $\mathrm{B}\left(5.5 \% \mathrm{P}_{2} \mathrm{O}_{5}\right)$ & 2.0 & 0.0 & 86.0 & 0.0 & 11.3 & 0.8 \\
\hline & Slag $\mathrm{C}\left(8.0 \% \mathrm{P}_{2} \mathrm{O}_{5}\right)$ & 1.8 & 0.0 & 86.8 & 0.0 & 11.1 & 0.3 \\
\hline & Slag D $\left(10.0 \% \mathrm{P}_{2} \mathrm{O}_{5}\right)$ & 1.2 & 0.0 & 87.4 & 0.0 & 11.0 & 0.3 \\
\hline \multirow{4}{*}{$\begin{array}{l}\text { Matrix } \\
\text { phase }\end{array}$} & Slag A $\left(3.0 \% \mathrm{P}_{2} \mathrm{O}_{5}\right)$ & 27.2 & 29.9 & 33.5 & 0.3 & 0.9 & 8.1 \\
\hline & Slag B $\left(5.5 \% \mathrm{P}_{2} \mathrm{O}_{5}\right)$ & 32.9 & 34.7 & 24.9 & 0.6 & 1.4 & 5.6 \\
\hline & Slag $\mathrm{C}\left(8.0 \% \mathrm{P}_{2} \mathrm{O}_{5}\right)$ & 34.4 & 33.1 & 25.9 & 1.1 & 1.5 & 3.9 \\
\hline & Slag D $\left(10.0 \% \mathrm{P}_{2} \mathrm{O}_{5}\right)$ & 36.0 & 34.9 & 22.0 & 2.1 & 1.7 & 3.4 \\
\hline \multirow{4}{*}{$\begin{array}{l}\text { Solid } \\
\text { solution }\end{array}$} & Slag A $\left(3.0 \% \mathrm{P}_{2} \mathrm{O}_{5}\right)$ & 56.5 & 27.6 & 1.9 & 9.4 & 0.4 & 4.2 \\
\hline & Slag B $\left(5.5 \% \mathrm{P}_{2} \mathrm{O}_{5}\right)$ & 53.4 & 21.4 & 1.3 & 17.5 & 0.5 & 6.0 \\
\hline & Slag C $\left(8.0 \% \mathrm{P}_{2} \mathrm{O}_{5}\right)$ & 51.4 & 15.6 & 0.9 & 25.4 & 0.3 & 6.4 \\
\hline & Slag D $\left(10.0 \% \mathrm{P}_{2} \mathrm{O}_{5}\right)$ & 50.7 & 10.6 & 0.6 & 31.0 & 0.3 & 6.8 \\
\hline \multirow{3}{*}{$\begin{array}{l}\text { Magnesio- } \\
\text { ferrite }\end{array}$} & Slag E $\left(24.0 \% \mathrm{Fe}_{2} \mathrm{O}_{3}\right)$ & 2.4 & 0.2 & 83.6 & 0.0 & 12.8 & 1.0 \\
\hline & Slag A $\left(30.6 \% \mathrm{Fe}_{2} \mathrm{O}_{3}\right)$ & 2.3 & 0.0 & 86.1 & 0.0 & 10.4 & 1.2 \\
\hline & Slag F $\left(36.0 \% \mathrm{Fe}_{2} \mathrm{O}_{3}\right)$ & 2.3 & 0.1 & 86.4 & 0.0 & 9.9 & 1.3 \\
\hline \multirow{3}{*}{$\begin{array}{l}\text { Matrix } \\
\text { phase }\end{array}$} & Slag E $\left(24.0 \% \mathrm{Fe}_{2} \mathrm{O}_{3}\right)$ & 26.8 & 30.2 & 33.0 & 0.3 & 1.2 & 8.5 \\
\hline & Slag A $\left(30.6 \% \mathrm{Fe}_{2} \mathrm{O}_{3}\right)$ & 27.2 & 29.9 & 33.5 & 0.3 & 0.9 & 8.1 \\
\hline & Slag F $\left(36.0 \% \mathrm{Fe}_{2} \mathrm{O}_{3}\right)$ & 25.6 & 30.4 & 33.6 & 0.3 & 0.8 & 9.3 \\
\hline \multirow{3}{*}{$\begin{array}{l}\text { Solid } \\
\text { solution }\end{array}$} & Slag E $\left(24.0 \% \mathrm{Fe}_{2} \mathrm{O}_{3}\right)$ & 57.5 & 29.1 & 1.8 & 7.3 & 0.7 & 3.7 \\
\hline & Slag A $\left(30.6 \% \mathrm{Fe}_{2} \mathrm{O}_{3}\right)$ & 56.5 & 27.6 & 1.9 & 9.4 & 0.4 & 4.2 \\
\hline & Slag F $\left(36.0 \% \mathrm{Fe}_{2} \mathrm{O}_{3}\right)$ & 55.2 & 25.9 & 1.6 & 11.8 & 0.3 & 5.1 \\
\hline
\end{tabular}
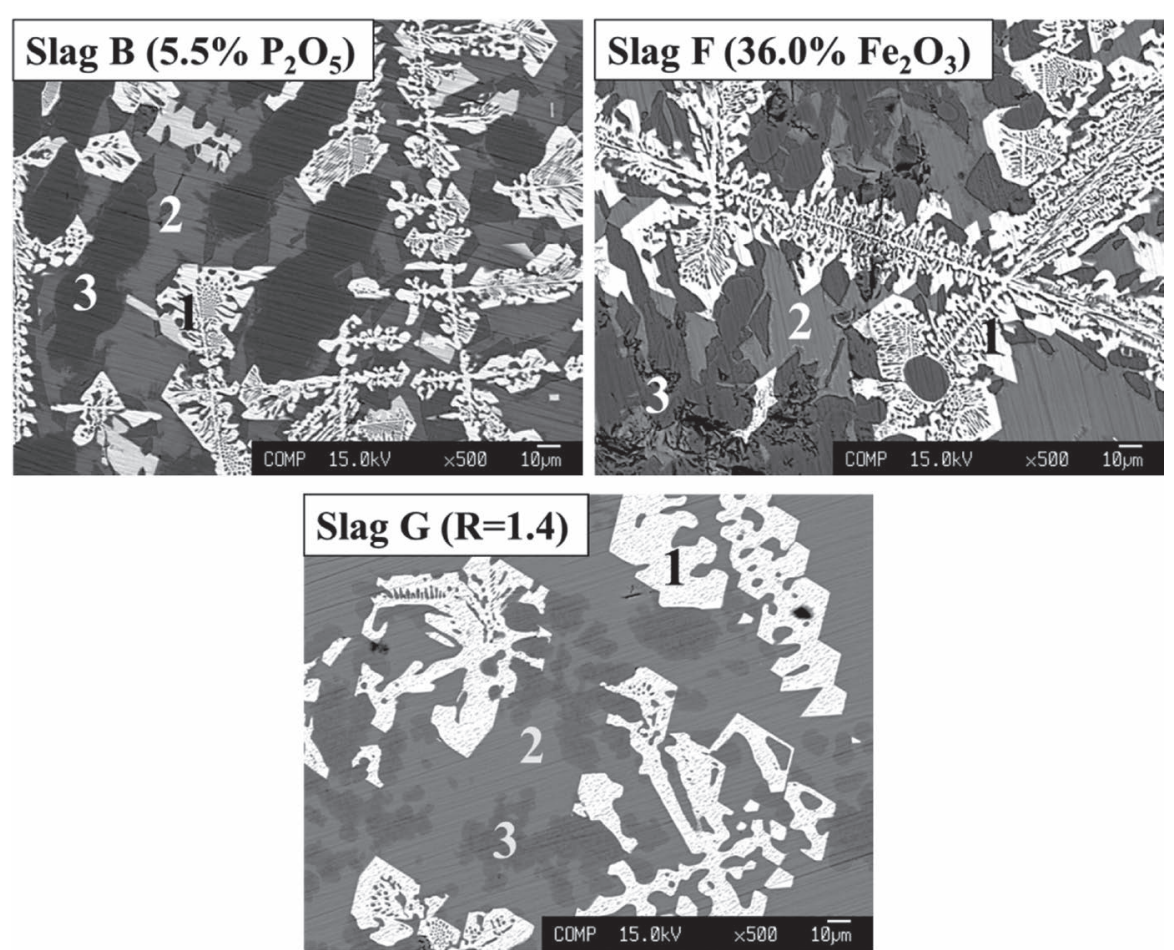

Fig. 2. Micrographs of the typical slags observed by EPMA (R denotes slag basicity). 
Table 4. Compositions of each phase in slags with different basicities (R) (mass\%).

\begin{tabular}{|c|c|c|c|c|c|c|c|c|c|}
\hline & & $\mathrm{CaO}$ & $\mathrm{SiO}_{2}$ & $\mathrm{Fe}_{2} \mathrm{O}_{3}$ & $\mathrm{P}_{2} \mathrm{O}_{5}$ & $\mathrm{MgO}$ & $\mathrm{MnO}$ & $\mathrm{Al}_{2} \mathrm{O}_{3}$ & $\mathrm{Na}_{2} \mathrm{O}$ \\
\hline \multirow{3}{*}{$\begin{array}{l}\text { Magnesio- } \\
\text { ferrite }\end{array}$} & $\begin{array}{c}\text { Slag G } \\
(\mathrm{R}=1.4)\end{array}$ & 1.1 & 0.0 & 76.6 & 0.0 & 12.0 & 9.5 & 0.7 & 0.1 \\
\hline & $\begin{array}{c}\text { Slag H } \\
(\mathrm{R}=1.7)\end{array}$ & 1.5 & 0.0 & 75.7 & 0.0 & 12.3 & 9.2 & 1.0 & 0.2 \\
\hline & $\begin{array}{c}\text { Slag I } \\
(\mathrm{R}=2.0)\end{array}$ & 2.1 & 0.1 & 77.0 & 0.0 & 10.3 & 8.3 & 1.4 & 0.8 \\
\hline \multirow{3}{*}{$\begin{array}{l}\text { Matrix } \\
\text { phase }\end{array}$} & $\begin{array}{c}\text { Slag G } \\
(\mathrm{R}=1.4)\end{array}$ & 34.1 & 38.6 & 15.7 & 2.3 & 2.4 & 1.4 & 1.9 & 3.8 \\
\hline & $\begin{array}{c}\text { Slag H } \\
(\mathrm{R}=1.7)\end{array}$ & 32.8 & 37.4 & 19.2 & 0.8 & 1.7 & 1.3 & 2.8 & 4.1 \\
\hline & $\begin{array}{c}\text { Slag I } \\
(\mathrm{R}=2.0)\end{array}$ & 27.6 & 33.3 & 25.1 & 0.4 & 0.9 & 0.9 & 4.7 & 7.1 \\
\hline \multirow{3}{*}{$\begin{array}{l}\text { Solid } \\
\text { solution }\end{array}$} & $\begin{array}{c}\text { Slag G } \\
(\mathrm{R}=1.4)\end{array}$ & 47.9 & 13.6 & 0.8 & 30.5 & 0.5 & 0.4 & 0.0 & 6.5 \\
\hline & $\begin{array}{c}\text { Slag H } \\
(\mathrm{R}=1.7)\end{array}$ & 50.3 & 17.6 & 0.7 & 24.3 & 0.4 & 0.3 & 0.0 & 6.4 \\
\hline & $\begin{array}{c}\text { Slag I } \\
(\mathrm{R}=2.0)\end{array}$ & 50.8 & 22.2 & 0.9 & 18.9 & 0.2 & 0.2 & 0.0 & 6.7 \\
\hline
\end{tabular}

$$
L_{\mathrm{Na} 2 \mathrm{O}}=\frac{\left(\% \mathrm{Na}_{2} \mathrm{O}\right)_{S S}}{\left(\% \mathrm{Na}_{2} \mathrm{O}\right)_{\text {Matrix }}}
$$

where $\left(\% \mathrm{P}_{2} \mathrm{O}_{5}\right)$ and $\left(\% \mathrm{Na}_{2} \mathrm{O}\right)$ represent the $\mathrm{P}_{2} \mathrm{O}_{5}$ and $\mathrm{Na}_{2} \mathrm{O}$ contents of each phase in mass\%; and subscripts $S S$ and Matrix denote the solid solution and matrix phase, respectively. Figure 3 shows the influence of slag composition on the distribution ratios of $\mathrm{P}_{2} \mathrm{O}_{5}$ and $\mathrm{Na}_{2} \mathrm{O}$ between solid solution and matrix phase. Comparing with the distribution ratio of $\mathrm{P}_{2} \mathrm{O}_{5}$ in the quenched slag, ${ }^{18)}$ the values of the present slags, which were cooled slowly, were far higher, indicating that the enrichment of $\mathrm{P}_{2} \mathrm{O}_{5}$ in the solid solution was promoted. Increasing the $\mathrm{P}_{2} \mathrm{O}_{5}$ content in slag led to a decrease in the distribution ratio of $\mathrm{P}_{2} \mathrm{O}_{5}$, while increasing the $\mathrm{Fe}_{2} \mathrm{O}_{3}$ content and slag basicity had an opposite effect. The distribution ratio of $\mathrm{Na}_{2} \mathrm{O}$ increased with the $\mathrm{P}_{2} \mathrm{O}_{5}$ and $\mathrm{Fe}_{2} \mathrm{O}_{3}$ contents in slag; in the case of high $\mathrm{P}_{2} \mathrm{O}_{5}$ content, its value was more than 1.5 , indicating that $\mathrm{Na}_{2} \mathrm{O}$ preferred to combine with $\mathrm{P}_{2} \mathrm{O}_{5}$. With the increase in slag basicity, the distribution ratio of $\mathrm{Na}_{2} \mathrm{O}$ decreased.

\subsection{Dissolution Behavior of Various Slags}

The changes in the concentrations of $\mathrm{Ca}, \mathrm{P}$, and $\mathrm{Fe}$ under various $\mathrm{P}_{2} \mathrm{O}_{5}$ contents in slag are shown in Fig. 4. The concentrations of each element in the aqueous solution increased with leaching time. The dissolution rate of each element was high in the initial stage because of the high concentration gradient between reaction interface and bulk solution, but their concentrations increased slowly after $60 \mathrm{~min}$. Ca concentration was the highest among all the elements, and nearly two orders of magnitudes higher than that of $\mathrm{Fe}$. $\mathrm{P}$ concentration was in a direct proportion to the $\mathrm{P}_{2} \mathrm{O}_{5}$ content in slag; in the case of slag containing 10 mass $\%$ of $\mathrm{P}_{2} \mathrm{O}_{5}$, it reached approximately $90 \mathrm{mg} / \mathrm{L}$. In contrast, the concentrations of $\mathrm{Ca}$ and $\mathrm{Fe}$ decreased with the increase in the $\mathrm{P}_{2} \mathrm{O}_{5}$ content in slag. When the $\mathrm{P}_{2} \mathrm{O}_{5}$ content changed from 3 to 10 mass $\%$, Ca concentration decreased
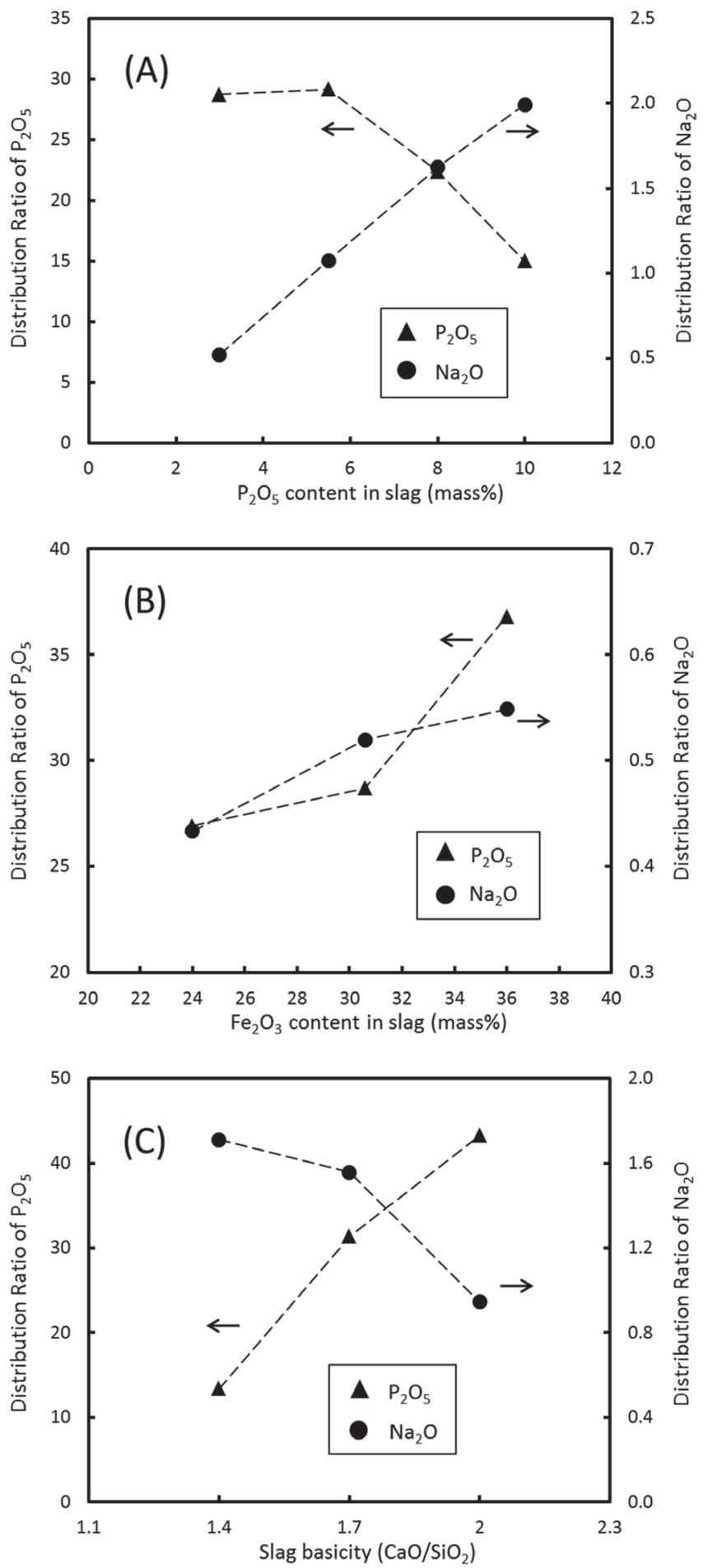

Fig. 3. Distribution ratios of $\mathrm{P}_{2} \mathrm{O}_{5}$ and $\mathrm{Na}_{2} \mathrm{O}$ between solid solution and matrix phase (A) effect of $\mathrm{P}_{2} \mathrm{O}_{5}$ content; (B) effect of $\mathrm{Fe}_{2} \mathrm{O}_{3}$ content; (C) effect of slag basicity.

from about 460 to $280 \mathrm{mg} / \mathrm{L}$, and Fe concentration was less than $4 \mathrm{mg} / \mathrm{L}$.

On the basis of the concentrations of each element in the leachate after $120 \mathrm{~min}$, the dissolution ratios of each element from slag were calculated by the following equation:

$$
R_{\mathrm{M}}=\frac{C_{\mathrm{M}} \cdot V}{m_{\mathrm{M}}}
$$

where $R_{\mathrm{M}}$ is the dissolution ratio of element $\mathrm{M} ; V$ is the final volume of the leachate (considering the volumes of the sampled solution and the added acid solution); $C_{\mathrm{M}}$ is the 

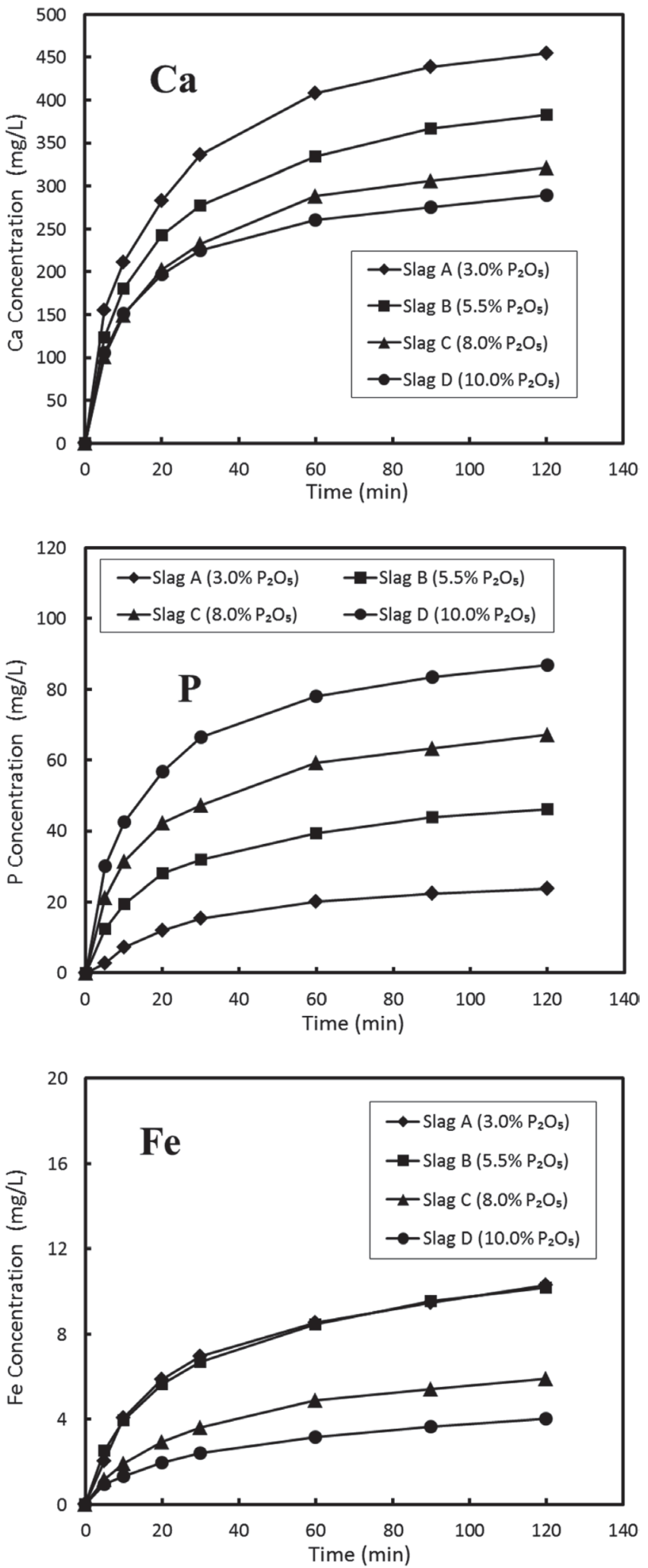

Fig. 4. Changes in the concentrations of $\mathrm{Ca}, \mathrm{P}$, and $\mathrm{Fe}$ under various $\mathrm{P}_{2} \mathrm{O}_{5}$ contents.

concentration of element $\mathrm{M}$ in the leachate $(\mathrm{mg} / \mathrm{L}) ; m_{\mathrm{M}}$ is the original mass of element $M$ in the slag $(\mathrm{mg})$. Figure 5 shows the calculated dissolution ratios of each element from slags with various $\mathrm{P}_{2} \mathrm{O}_{5}$ contents. The dissolution ratio of $\mathrm{P}$ was the highest in each case, reaching approximately $76 \%$ regardless of the $\mathrm{P}_{2} \mathrm{O}_{5}$ content in the slag. The dissolution ratios of $\mathrm{Fe}$ and $\mathrm{Mg}$ were far lower than those of other elements, especially Fe (less than $2 \%$ ). This result indicates

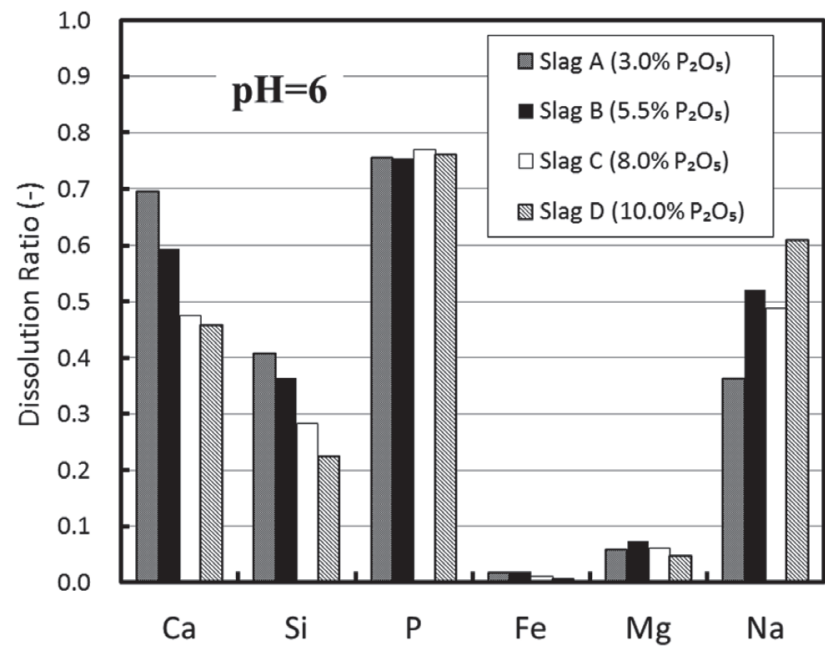

Fig. 5. Dissolution ratios of each element from slags with various $\mathrm{P}_{2} \mathrm{O}_{5}$ contents.

that the matrix phase and magnesioferrite in which Fe and $\mathrm{Mg}$ were mainly distributed were resistant to dissolution. With the increase in the $\mathrm{P}_{2} \mathrm{O}_{5}$ content, the amount of the dissolved slag reduced because of a significant decrease in the dissolution ratios of $\mathrm{Ca}$ and $\mathrm{Si}$. In the case of high $\mathrm{P}_{2} \mathrm{O}_{5}$ content, most of the $\mathrm{P}$ was dissolved, and the dissolution ratios of $\mathrm{Ca}$ and $\mathrm{Si}$ were less than $50 \%$ and $30 \%$, respectively, exhibiting a better selective leaching of $\mathrm{P}$.

The dissolution ratios of each element from slags with various $\mathrm{Fe}_{2} \mathrm{O}_{3}$ contents calculated by the above method are shown in Fig. 6. The major ions dissolved from the slags were those of $\mathrm{Ca}, \mathrm{Si}$, and $\mathrm{P}$; the dissolution of $\mathrm{Fe}$ was minimal. Because of the lower $\mathrm{P}_{2} \mathrm{O}_{5}$ content in each slag, the dissolution of slag was significant, resulting in higher dissolution ratios of $\mathrm{Ca}$ and $\mathrm{Si}$. With the increase in the $\mathrm{Fe}_{2} \mathrm{O}_{3}$ content in slag, the dissolution ratio of $\mathrm{P}$ increased, while those of other elements decreased. In particular, the dissolution ratio of $\mathrm{Mg}$ decreased several times when the $\mathrm{Fe}_{2} \mathrm{O}_{3}$ content increased from 24.0 to 30.6 mass \%. In the case of high $\mathrm{Fe}_{2} \mathrm{O}_{3}$ content, the dissolution ratio of $\mathrm{P}$ reached $80 \%$, and about $70 \%$ of the $\mathrm{Ca}$ and $40 \%$ of the Si was also dissolved. Overall, increasing the $\mathrm{Fe}_{2} \mathrm{O}_{3}$ content in slag was beneficial for selective leaching of $\mathrm{P}$ from slag.

Figure 7 shows the changes in the concentrations of $\mathrm{Ca}$, $\mathrm{P}$, and Fe under different slag basicities. The concentration of Ca was far higher than those of other elements. With the increase in slag basicity, the concentrations of $\mathrm{Ca}$ and $\mathrm{P}$ both increased. When the basicity changed from 1.4 to $2.0, \mathrm{Ca}$ concentration almost doubled, and $\mathrm{P}$ concentration increased from 56.7 to $70.9 \mathrm{mg} / \mathrm{L}$. Fe was difficult to dissolve and its concentration was only several $\mathrm{mg} / \mathrm{L}$ in each case.

As shown in Fig. 8, Ca, Si, P, and $\mathrm{Na}$ were more readily dissolved from slag, exhibiting higher dissolution ratios. The dissolution ratio of $\mathrm{Fe}$ was the lowest, less than $2 \%$ in each case. Compared with other slags, the presence of $\mathrm{MnO}$ and $\mathrm{Al}_{2} \mathrm{O}_{3}$ in slag had little influence on the dissolution behavior of $\mathrm{P}$ and Fe. The dissolution of $\mathrm{Mn}$ and $\mathrm{Al}$ was not significant, similar with that of $\mathrm{Mg}$ and Fe. With the increase in slag basicity, the dissolution ratios of $\mathrm{Ca}, \mathrm{Si}$, and $\mathrm{P}$ increased significantly. In the case of high basicity, although almost all of the $\mathrm{P}$ was dissolved from slag, the dissolution ratio of $\mathrm{Ca}$ increased to $82 \%$ and half of the $\mathrm{Si}$ 


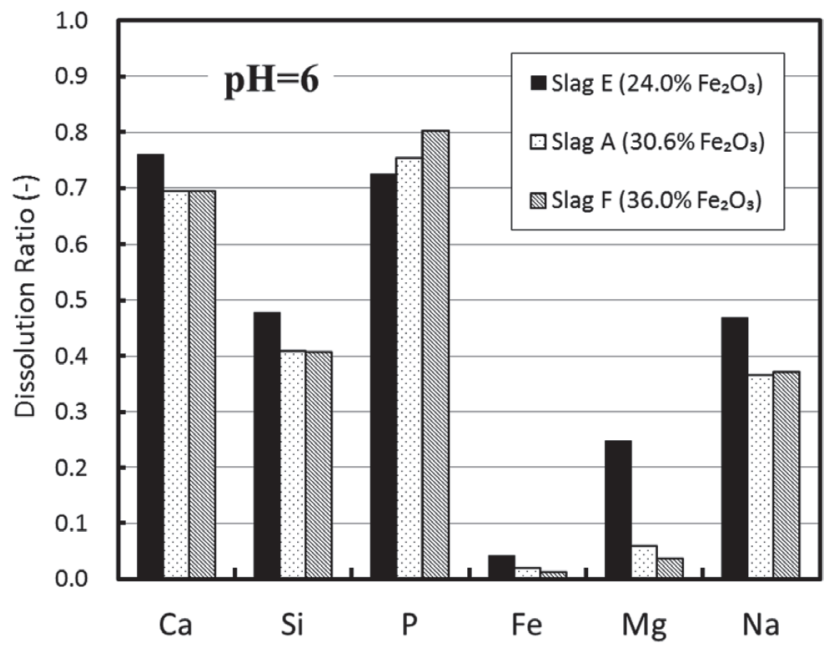

Fig. 6. Dissolution ratios of each element from slags with various $\mathrm{Fe}_{2} \mathrm{O}_{3}$ contents.
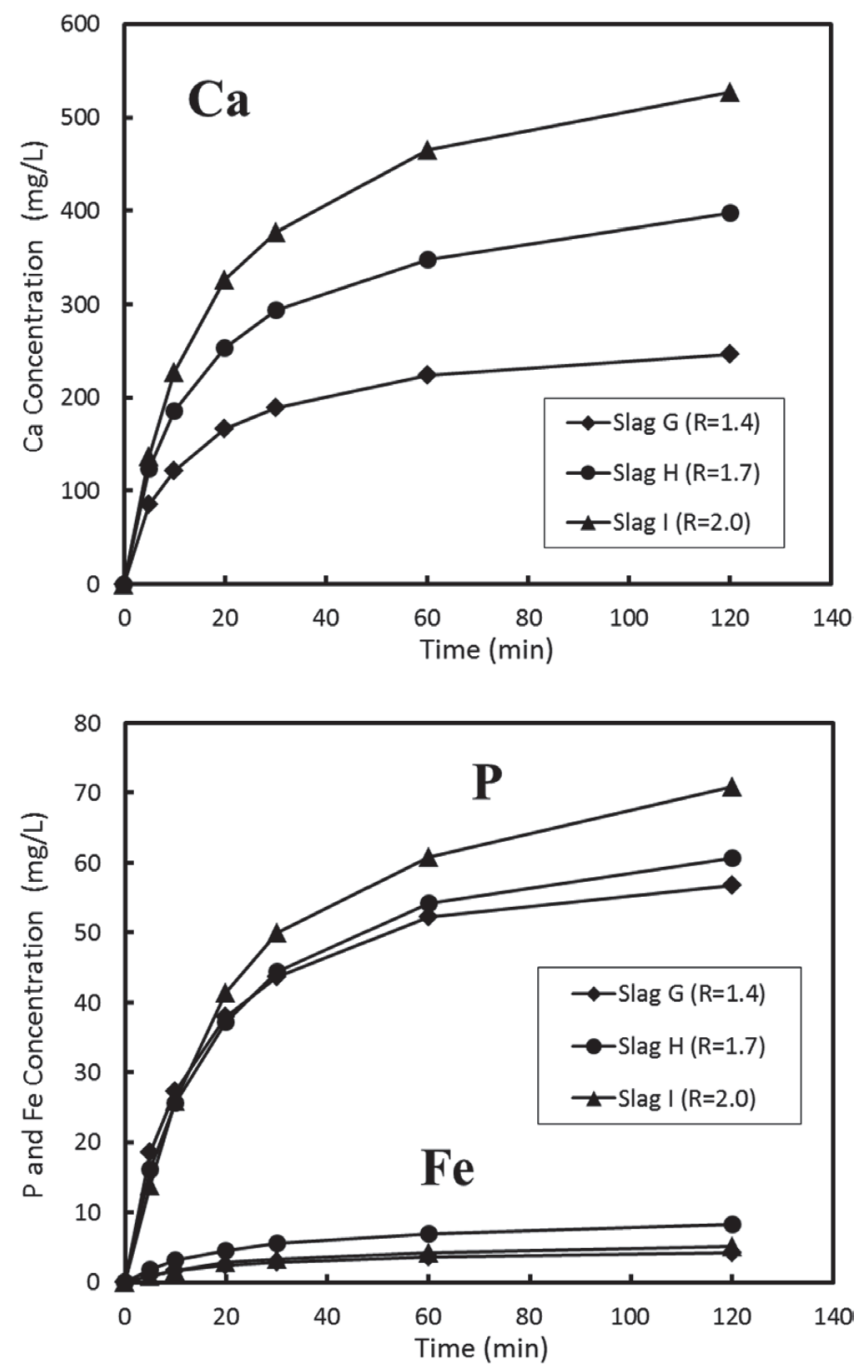

Fig. 7. Changes in the concentrations of $\mathrm{Ca}, \mathrm{P}$, and $\mathrm{Fe}$ under different slag basicities (R).

was also dissolved. When slag basicity decreased to 1.4 , the dissolution ratio of $\mathrm{P}$ reached approximately $72 \%$ and only a small fraction of Si was dissolved. In addition, the consumption of citric acid during leaching was smaller compared with that under higher basicity. To achieve a better selective leaching of $\mathrm{P}$, slag basicity should be not too high to avoid

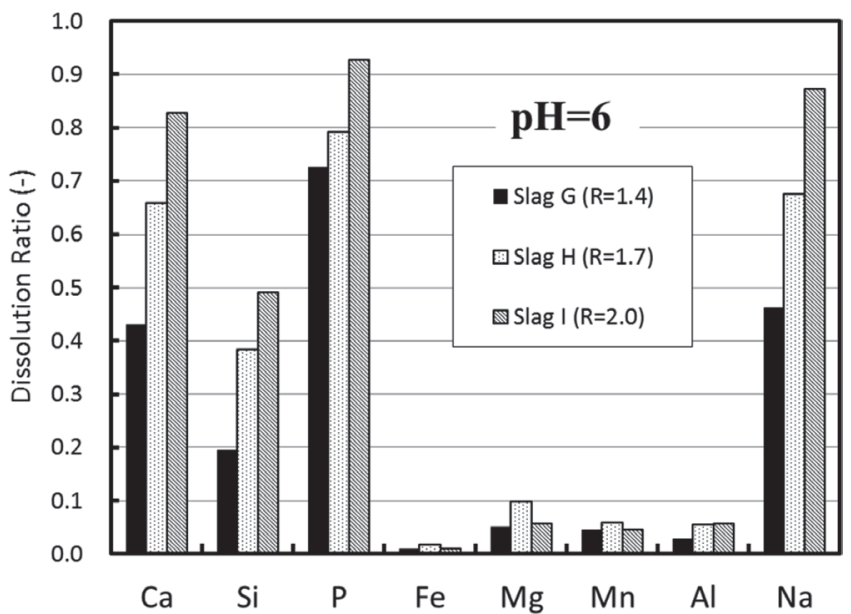

Fig. 8. Dissolution ratios of each element from slags with different basicities (R).

Table 5. Compositions of the residue after leaching at $\mathrm{pH} 6$ (mass\%).

\begin{tabular}{ccccccc}
\hline Residue & $\mathrm{CaO}$ & $\mathrm{SiO}_{2}$ & $\mathrm{Fe}_{2} \mathrm{O}_{3}$ & $\mathrm{P}_{2} \mathrm{O}_{5}$ & $\mathrm{MgO}$ & $\mathrm{Na}_{2} \mathrm{O}$ \\
\hline Slag A $\left(3.0 \% \mathrm{P}_{2} \mathrm{O}_{5}\right)$ & 16.06 & 20.66 & 52.32 & 0.79 & 5.33 & 4.83 \\
Slag B $\left(5.5 \% \mathrm{P}_{2} \mathrm{O}_{5}\right)$ & 21.37 & 19.61 & 49.21 & 1.28 & 5.06 & 3.47 \\
Slag C $\left(8.0 \% \mathrm{P}_{2} \mathrm{O}_{5}\right)$ & 26.17 & 19.20 & 44.85 & 2.09 & 4.59 & 3.10 \\
Slag D $\left(10.0 \% \mathrm{P}_{2} \mathrm{O}_{5}\right)$ & 26.12 & 20.38 & 44.01 & 1.95 & 4.59 & 2.95 \\
\hline Slag E $\left(24.0 \% \mathrm{Fe}_{2} \mathrm{O}_{3}\right)$ & 16.72 & 27.57 & 44.58 & 1.35 & 5.27 & 4.47 \\
Slag F $\left(36.0 \% \mathrm{Fe}_{2} \mathrm{O}_{3}\right)$ & 14.78 & 18.32 & 57.07 & 0.66 & 4.63 & 4.48 \\
\hline Slag G $(\mathrm{R}=1.4)$ & 24.88 & 22.34 & 38.72 & 1.99 & 5.52 & 2.72 \\
Slag H $(\mathrm{R}=1.7)$ & 19.80 & 18.77 & 46.69 & 1.93 & 6.29 & 2.52 \\
Slag I $(\mathrm{R}=2.0)$ & 13.32 & 17.10 & 53.82 & 1.58 & 7.05 & 2.08 \\
\hline
\end{tabular}

a large dissolution of $\mathrm{Ca}$ and $\mathrm{Si}$.

\subsection{Residue Composition}

The average compositions of residues obtained after leaching at $\mathrm{pH} 6$ are listed in Table 5. Compared with the original slag (listed in Table 2), the $\mathrm{P}_{2} \mathrm{O}_{5}$ content in the residue decreased significantly corresponding to an increase in the $\mathrm{Fe}_{2} \mathrm{O}_{3}$ content. Because the dissolution ratio of $\mathrm{P}$ from slags with various $\mathrm{P}_{2} \mathrm{O}_{5}$ contents was almost the same, a higher $\mathrm{P}_{2} \mathrm{O}_{5}$ content in the original slag resulted in a higher $\mathrm{P}_{2} \mathrm{O}_{5}$ content in its residue. In the case of slag with high $\mathrm{P}_{2} \mathrm{O}_{5}$ content, the $\mathrm{P}_{2} \mathrm{O}_{5}$ content in the residue reached approximately 2.0 mass $\%$. With the increase in the $\mathrm{P}_{2} \mathrm{O}_{5}$ content in slag, the $\mathrm{CaO}$ content in the residue increased and the $\mathrm{Fe}_{2} \mathrm{O}_{3}$ content decreased. For the slag with high $\mathrm{Fe}_{2} \mathrm{O}_{3}$ content, a residue with lower $\mathrm{P}_{2} \mathrm{O}_{5}$ content and higher $\mathrm{Fe}_{2} \mathrm{O}_{3}$ content was obtained as the result of the excellent selective leaching of $\mathrm{P}$. With the increase in slag basicity, the $\mathrm{P}_{2} \mathrm{O}_{5}$ and $\mathrm{CaO}$ contents in the residue decreased and $\mathrm{Fe}_{2} \mathrm{O}_{3}$ content increased.

Figure 9 shows the XRD patterns of slags with various $\mathrm{P}_{2} \mathrm{O}_{5}$ contents and their residues. Two crystalline phases were observed in each slag. The crystal form of the solid solution was changed with the variation of $\mathrm{P}_{2} \mathrm{O}_{5}$ content in slag. Through selective leaching of $\mathrm{P}$, the peaks asso- 

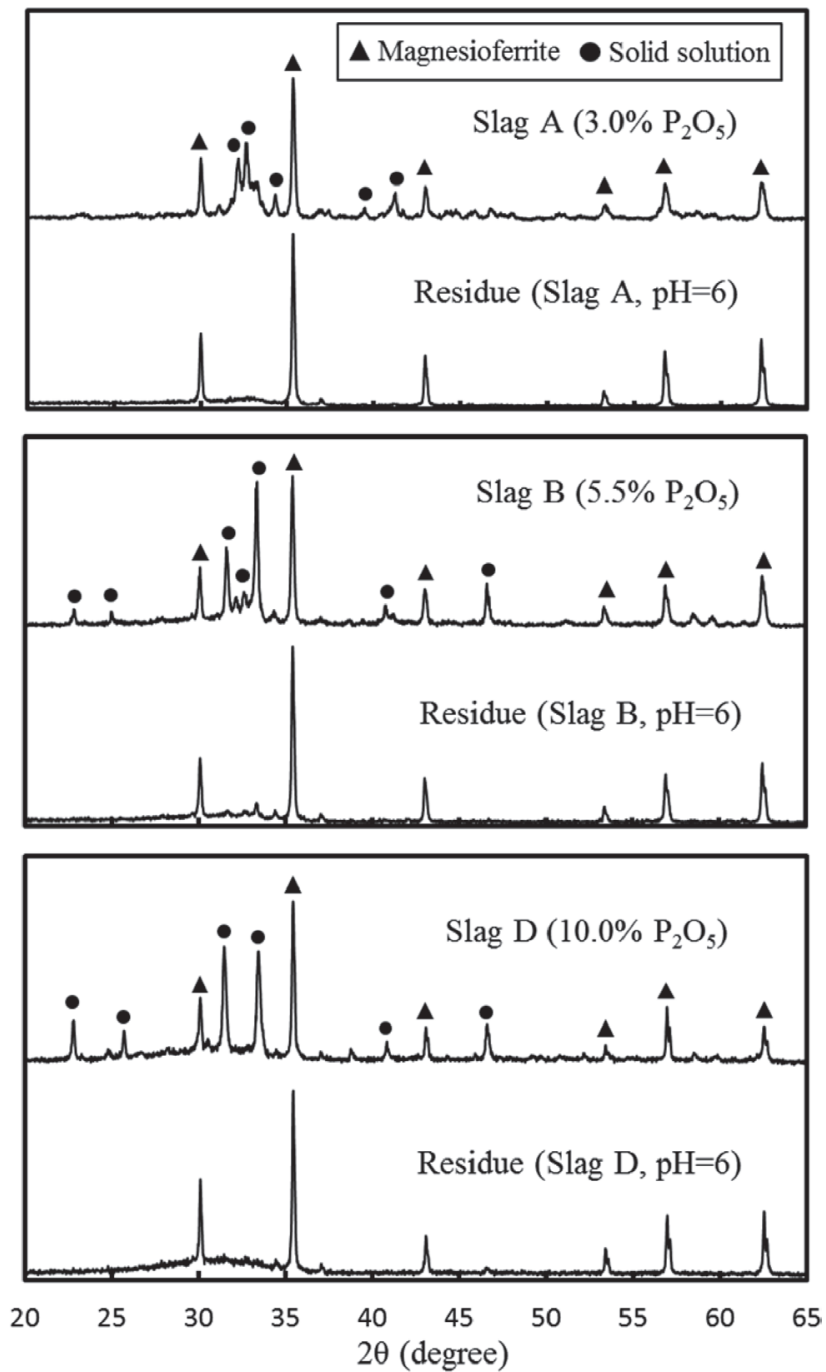

Fig. 9. XRD patterns for slags with various $\mathrm{P}_{2} \mathrm{O}_{5}$ contents and their residues.

ciated with solid solution almost disappeared regardless of the $\mathrm{P}_{2} \mathrm{O}_{5}$ content in slag, and those associated with magnesioferrite intensified. These results indicated that the P-concentrated solid solution was easily dissolved in the aqueous solution and thereby separated from the slag, while other phases remained in the residue. Therefore, the P-removed slag has a potential to be recycled within the ironmaking and steelmaking process.

\section{Discussion}

Because of the formation of soluble complexes between $\mathrm{C}_{6} \mathrm{H}_{5} \mathrm{O}_{7}{ }^{3-}$ and $\mathrm{Ca}^{2+}$ ions in the citric acid solution, ${ }^{13)}$ $\mathrm{Ca}_{10}\left(\mathrm{PO}_{4}\right)_{6}(\mathrm{OH})_{2}$ is difficult to precipitate in this case. ${ }^{15,17)}$ Therefore, the precipitation of calcium phosphate was ignored in this study. The measured content in the aqueous solution is considered to be the dissolved $\mathrm{P}$ content without precipitates. To evaluate the dissolution behavior of each phase, the mass fractions of each phase in slag were compared with those of the dissolved mass and residue. First, the mass fractions of each phase in different slags were calculated using the above EPMA results (listed in Tables 3 and 4). The mass balance of each oxide and phase fraction can be expressed as:

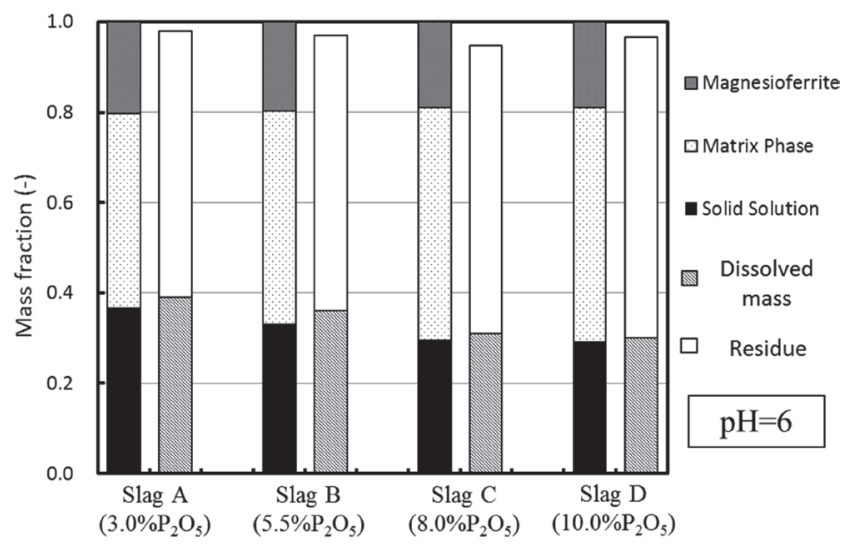

Fig. 10. Fractions of the dissolved mass and residue, compared with phase fractions of slags with various $\mathrm{P}_{2} \mathrm{O}_{5}$ contents.

$$
\begin{aligned}
(\% \mathrm{MO})_{\text {slag }}= & \alpha(\% \mathrm{MO})_{S S} \\
+ & \beta(\% \mathrm{MO})_{\text {Matrix }}+\gamma(\% \mathrm{MO})_{M F} \\
& \alpha+\beta+\gamma=1 \ldots \ldots \ldots \ldots \ldots \ldots \ldots \ldots \ldots \ldots \ldots \ldots \ldots \ldots
\end{aligned}
$$

where $\alpha, \beta$, and $\gamma$ are the mass fractions of solid solution, matrix phase, and magnesioferrite respectively, and the subscript $M F$ denotes the magnesioferrite. By the combination of mass balance of $\mathrm{CaO}, \mathrm{SiO}_{2}, \mathrm{Fe}_{2} \mathrm{O}_{3}$, and $\mathrm{P}_{2} \mathrm{O}_{5}$, the mass fraction of each phase can be evaluated. The calculated phase fraction of slags with various $\mathrm{P}_{2} \mathrm{O}_{5}$ contents is shown in Fig. 10. With the increase in the $\mathrm{P}_{2} \mathrm{O}_{5}$ content in slag, the mass fraction of solid solution decreased and that of matrix phase increased correspondingly; there was a little change in the mass fraction of magnesioferrite. On the basis of the dissolution ratios of each element, the fraction of the dissolved mass $\left(R_{\text {dissolved }}\right)$ is calculated as:

$$
R_{\text {dissolved }}=\sum\left(R_{\mathrm{M}} \cdot(\% \mathrm{MO})_{\text {slag }}\right) / 100
$$

The mass fraction of the residue is obtained by weighting the mass of the dried slag after leaching. As shown in Fig. 10, the fraction of the dissolved mass also decreased with the increase in the $\mathrm{P}_{2} \mathrm{O}_{5}$ content, and its value was a little higher than that of solid solution. The lower dissolution ratio of $\mathrm{Fe}$ illustrates that the dissolution of the Fe-concentrated matrix phase and magnesioferrite was not large. Consequently, it was determined that, independent of the $\mathrm{P}_{2} \mathrm{O}_{5}$ content, most of the solid solution was dissolved from the slag.

Assuming that only solid solution was dissolved, the dissolution ratios of each element from the slag were calculated by Eq. (7).

$$
R_{\mathrm{M}}^{\text {Cal. }}=\frac{\alpha \cdot(\% \mathrm{MO})_{S S}}{(\% \mathrm{MO})_{\text {slag }}}
$$

where $R_{\mathrm{M}}^{\text {Cal. }}$ is the calculated dissolution ratio of $\mathrm{M}$, which is actually equal to the mass fraction of MO distributed in the solid solution. As most of the $\mathrm{P}$ was concentrated in the solid solution, the dissolution ratio of solid solution $\left(R_{S S}\right)$ can be evaluated using Eq. (8):

$$
R_{S S}=\frac{R_{\mathrm{P}}}{R_{\mathrm{P}}^{\text {Cal. }}}
$$




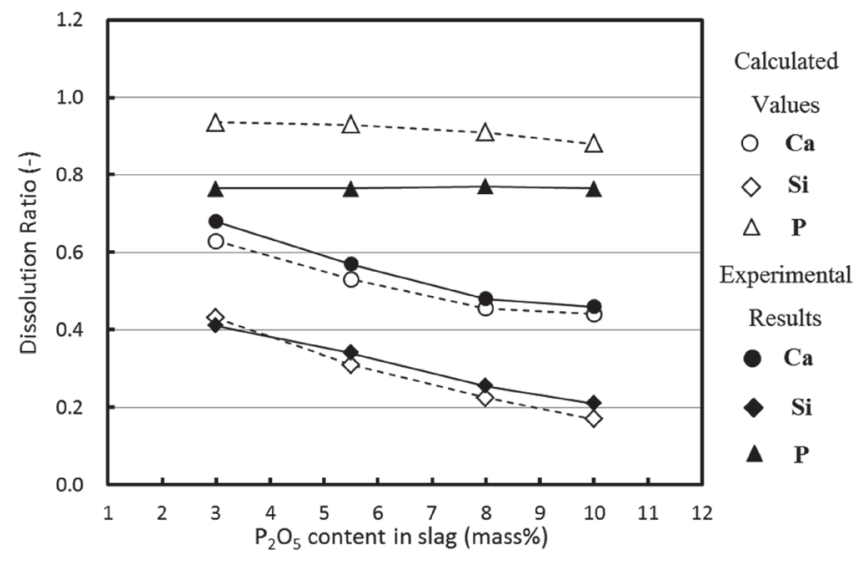

Fig. 11. Calculated dissolution ratios of each element and experimental results under various $\mathrm{P}_{2} \mathrm{O}_{5}$ contents.

Figure 11 shows the calculated dissolution ratios and experimental results. As the experimental values of $\mathrm{P}$ were close to the calculated values, this result indicated that most of the solid solution was dissolved irrespective to the $\mathrm{P}_{2} \mathrm{O}_{5}$ content. In general, the increase in the $\mathrm{P}_{2} \mathrm{O}_{5}$ content in the solid solution deteriorates its solubility in the aqueous solution. ${ }^{9)}$ However, the addition of $\mathrm{Na}_{2} \mathrm{O}$ renders the solid solution more readily soluble. ${ }^{15)}$ The difference between the calculation and experimental results narrowed with the increase in the $\mathrm{P}_{2} \mathrm{O}_{5}$ content. As listed in Table 6, the dissolution ratio of solid solution increased from $81.8 \%$ to $86.9 \%$ when the $\mathrm{P}_{2} \mathrm{O}_{5}$ content changed from 3 to 10 mass $\%$, resulting from the increase of the $\mathrm{Na}_{2} \mathrm{O}$ content in the solid solution. With the increase in the $\mathrm{P}_{2} \mathrm{O}_{5}$ content in slag, the calculated dissolution ratios of $\mathrm{Ca}$ and $\mathrm{Si}$ decreased because more $\mathrm{Ca}$ and $\mathrm{Si}$ were distributed in the matrix phase. In each case, the experimental values and the calculated values for $\mathrm{Ca}$ and $\mathrm{Si}$ were much closer than that for $\mathrm{P}$. As $\mathrm{Ca}$ and $\mathrm{Si}$ is distributed between the solid solution and matrix phase, a part of the dissolved $\mathrm{Ca}$ and $\mathrm{Si}$ might have been supplied from the matrix phase. Using these results and the dissolution ratio of solid solution, the dissolution ratio of matrix phase can be estimated as follows:

$$
R_{\text {Matrix }}=\frac{\left(R_{\mathrm{M}}-R_{S S} \cdot R_{\mathrm{M}}^{\text {Cal. }}\right)}{1-R_{\mathrm{M}}^{\text {Cal. }}}
$$

Its value is defined as the average of the calculated results for $\mathrm{Ca}$ and $\mathrm{Si}$. Table 6 shows that the dissolution ratio of matrix phase was not so large and decreased with the increase in the $\mathrm{P}_{2} \mathrm{O}_{5}$ content in slag. The slag with high $\mathrm{P}_{2} \mathrm{O}_{5}$ content performs a better selective leaching of solid solution.

On the basis of the concentrations of each element in the leachate, the composition of the dissolved part was evaluated as follows:

$$
(\% \mathrm{MO})_{\text {Cal. }}=\frac{C_{\mathrm{M}} \cdot V \cdot \mathrm{M}_{\mathrm{MO}} / \mathrm{M}_{\mathrm{M}}}{R_{\text {dissolved }} \cdot m_{\text {slag }}} \times 100 \%
$$

where $(\% \mathrm{MO})_{\text {cal }}$. denotes the calculated $\mathrm{MO}$ content in the dissolved part, $m_{\text {slag }}$ is the mass of slag during leaching (mg), and $\mathrm{M}$ is the molar mass. In Fig. 12, the compositions of the dissolved parts are compared with those of solid solution in slags with various $\mathrm{P}_{2} \mathrm{O}_{5}$ contents. The dissolved
Table 6. Dissolution ratios of solid solution and matrix phase from each slag.

\begin{tabular}{ccc}
\hline Sample & $\begin{array}{c}\text { Dissolution ratio of } \\
\text { solid solution }\end{array}$ & $\begin{array}{c}\text { Dissolution ratio of } \\
\text { matrix phase }\end{array}$ \\
\hline Slag A $\left(3.0 \% \mathrm{P}_{2} \mathrm{O}_{5}\right)$ & 0.818 & 0.273 \\
Slag B $\left(5.5 \% \mathrm{P}_{2} \mathrm{O}_{5}\right)$ & 0.823 & 0.204 \\
Slag C $\left(8.0 \% \mathrm{P}_{2} \mathrm{O}_{5}\right)$ & 0.846 & 0.128 \\
Slag D $\left(10.0 \% \mathrm{P}_{2} \mathrm{O}_{5}\right)$ & 0.869 & 0.106 \\
\hline Slag E $\left(24.0 \% \mathrm{Fe}_{2} \mathrm{O}_{3}\right)$ & 0.780 & 0.431 \\
Slag F $\left(36.0 \% \mathrm{Fe}_{2} \mathrm{O}_{3}\right)$ & 0.847 & 0.258 \\
\hline Slag $\mathrm{G}(\mathrm{R}=1.4)$ & 0.869 & 0.130 \\
Slag $\mathrm{H}(\mathrm{R}=1.7)$ & 0.871 & 0.287 \\
Slag I $(\mathrm{R}=2.0)$ & 0.964 & 0.267 \\
\hline
\end{tabular}

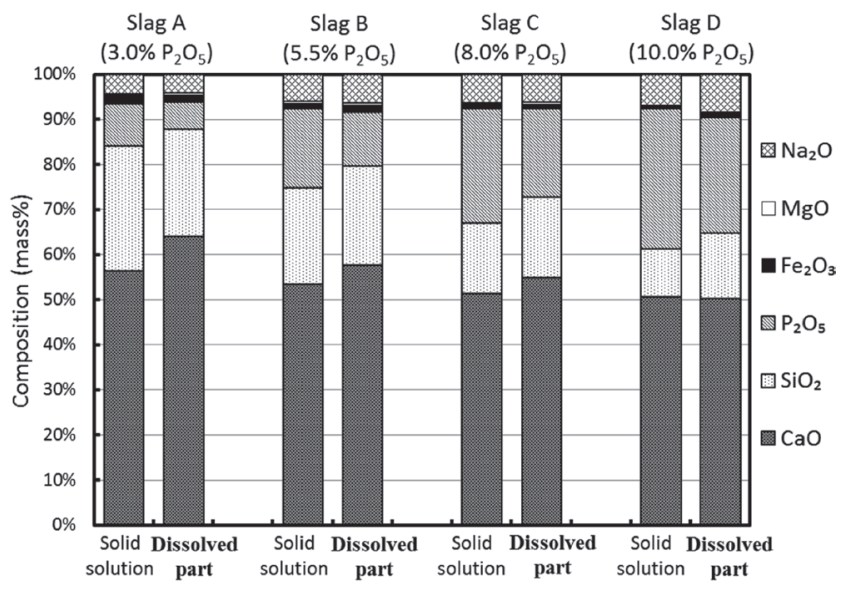

Fig. 12. Compositions of solid solution and the dissolved part.

part mainly consisted of $\mathrm{CaO}, \mathrm{SiO}_{2}$, and $\mathrm{P}_{2} \mathrm{O}_{5}$, which was consistent with the solid solution. In the case of slag with low $\mathrm{P}_{2} \mathrm{O}_{5}$ content, the $\mathrm{CaO}$ and $\mathrm{SiO}_{2}$ contents in the dissolved part was high while the $\mathrm{P}_{2} \mathrm{O}_{5}$ content was lower, less than 8 mass $\%$. The difference in composition between the solid solution and the dissolved part is attributed to the dissolution of matrix phase. With the increase in the $\mathrm{P}_{2} \mathrm{O}_{5}$ content in slag, the $\mathrm{CaO}$ and $\mathrm{SiO}_{2}$ contents in the dissolved part decreased and the $\mathrm{P}_{2} \mathrm{O}_{5}$ content increased. For the slag with 10 mass $\%$ of $\mathrm{P}_{2} \mathrm{O}_{5}$, the $\mathrm{P}_{2} \mathrm{O}_{5}$ content in the dissolved part reached 26 mass $\%$. The composition of the dissolved part was similar with that of the solid solution indicating that the dissolution of matrix phase was slight, in agreement with the above calculations. Owing to the high $\mathrm{P}_{2} \mathrm{O}_{5}$ content, the leachate obtained from the slag with high $\mathrm{P}_{2} \mathrm{O}_{5}$ content is more suitable to be treated in the subsequent process of $\mathrm{P}$ recovery.

The phase fractions of slags with various $\mathrm{Fe}_{2} \mathrm{O}_{3}$ contents were calculated, and compared with the fractions of the dissolved mass and residue in Fig. 13. With the increase in the $\mathrm{Fe}_{2} \mathrm{O}_{3}$ content in slag, the mass fraction of solid solution decreased while that of magnesioferrite increased. Because the composition of slag with high $\mathrm{Fe}_{2} \mathrm{O}_{3}$ content was closer to the liquidus of the $2 \mathrm{CaO} \cdot \mathrm{SiO}_{2}$ saturated region in the $\mathrm{CaO}-\mathrm{SiO}_{2}-\mathrm{Fe}_{2} \mathrm{O}_{3}$ phase diagram and the mass fraction of magnesioferrite was higher, the amount of $\mathrm{C}_{2} \mathrm{~S}-\mathrm{C}_{3} \mathrm{P}$ solid 


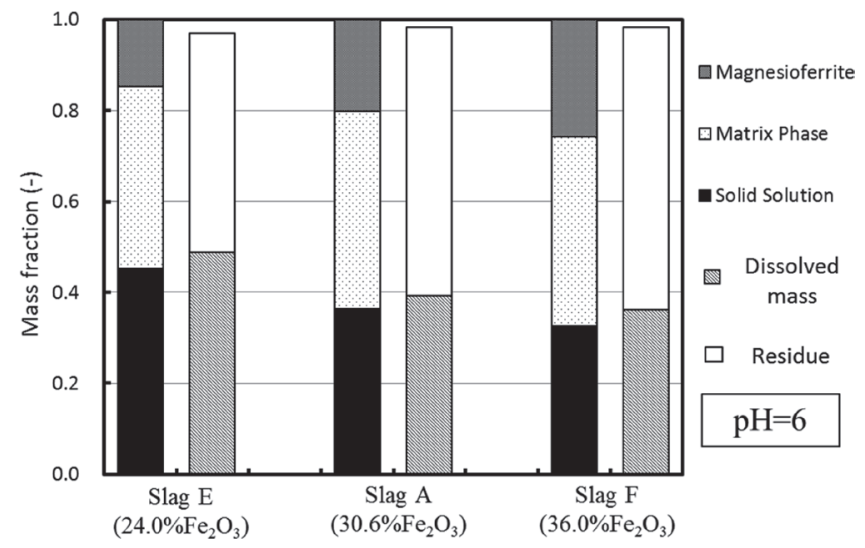

Fig. 13. Fractions of the dissolved mass and residue compared with phase fraction of slags with various $\mathrm{Fe}_{2} \mathrm{O}_{3}$ contents.

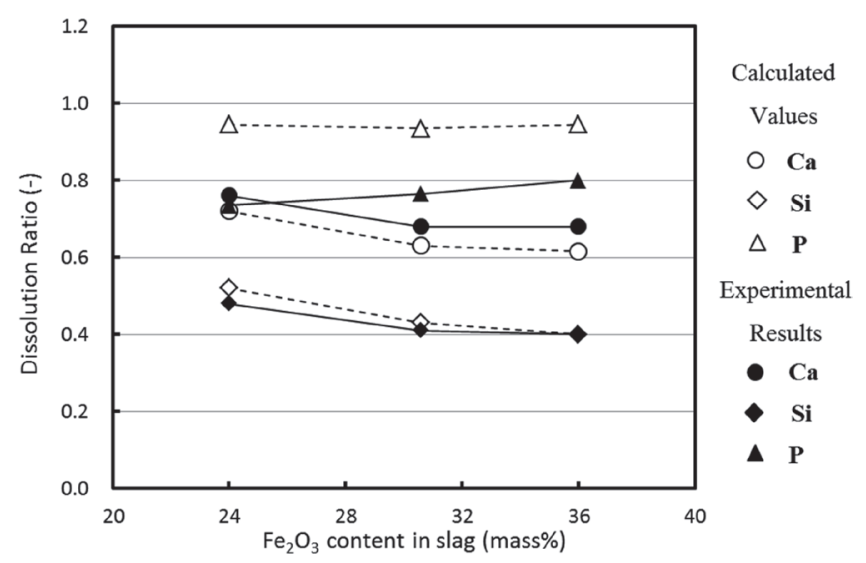

Fig. 14. Calculated dissolution ratios of each element and experimental results under various $\mathrm{Fe}_{2} \mathrm{O}_{3}$ contents.

solution in this slag was less than that in the slag with low $\mathrm{Fe}_{2} \mathrm{O}_{3}$ content. Although the fraction of the dissolved mass was decreased by increasing the $\mathrm{Fe}_{2} \mathrm{O}_{3}$ content in slag, it was higher than that of solid solution in each case. These results indicate that the majority of the solid solution was dissolved from slag.

Figure 14 shows the experimental results and the calculated dissolution ratios of each element when the solid solution alone was dissolved. With the increase in the $\mathrm{Fe}_{2} \mathrm{O}_{3}$ content in slag, the dissolution ratio of $\mathrm{P}$ gradually approached the calculated value, indicating that the dissolution of solid solution was promoted. As listed in Table 6, the dissolution ratio of solid solution reached approximately $85 \%$ in the case of high $\mathrm{Fe}_{2} \mathrm{O}_{3}$ content. This is because a higher $\mathrm{Na}_{2} \mathrm{O}$ content in the solid solution caused higher water solubility. The calculated dissolution ratios of $\mathrm{Ca}$ and $\mathrm{Si}$ decreased with the increase in the $\mathrm{Fe}_{2} \mathrm{O}_{3}$ content in slag, resulting from a decrease in the mass fraction of solid solution. These values were close to the experimental values. As mentioned above, the dissolution ratio of matrix phase was evaluated using these results. Table 6 shows that a part of the matrix phase was dissolved from the slag with low $\mathrm{Fe}_{2} \mathrm{O}_{3}$ content. This is the primary reason for a higher dissolution ratio of $\mathrm{Mg}$ from this slag, shown in Fig. 6. Increasing the $\mathrm{Fe}_{2} \mathrm{O}_{3}$ content in slag significantly suppressed the dissolution of matrix phase. In this case, the dissolution ratio of

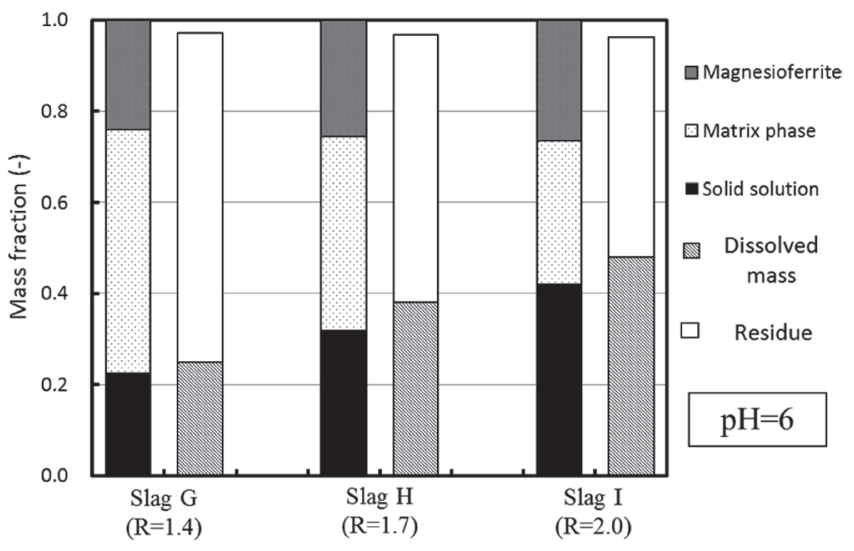

Fig. 15. Fractions of the dissolved mass and residue compared with phase fraction of slags with different basicities.

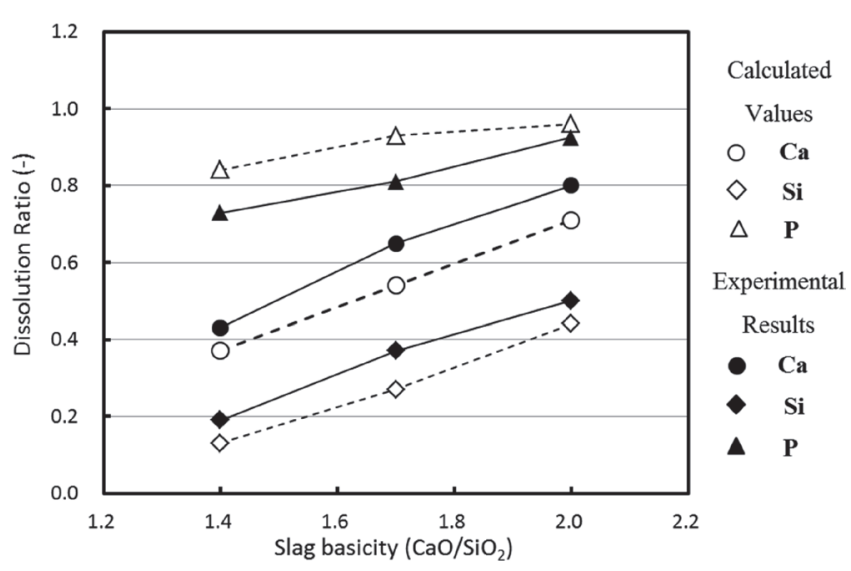

Fig. 16. Calculated dissolution ratios of each element and experimental results under different basicities.

matrix phase was lower, which was beneficial for selective leaching of P.

Figure 15 shows the fractions of the dissolved mass and residue, compared with phase fraction of slags with different basicities. Increasing slag basicity resulted in a higher mass fraction of solid solution. In the case of low basicity, approximately $25 \%$ of slag was dissolved; this value was similar to the mass fraction of solid solution. The dissolution of slag was significantly promoted by increasing slag basicity. However, the fraction of the dissolved mass did not greatly exceed that of solid solution, indicating that the solid solution was selectively dissolved.

Figure 16 shows the calculated dissolution ratios of $\mathrm{Ca}$, $\mathrm{Si}$, and $\mathrm{P}$ when the solid solution alone was dissolved under different basicities. These values all increased with slag basicity because of the enlargement of the solid solution. The dissolution ratio of $\mathrm{P}$ was close to the calculated value in each case. Calculation demonstrated that more than $87 \%$ of the solid solution was dissolved from slag. The slag with high basicity gave the highest dissolution ratio of solid solution. The dissolution ratios of $\mathrm{Ca}$ and $\mathrm{Si}$ were a little higher than the calculated values, showing that a part of matrix phase was also dissolved. As listed in Table 6, the dissolution ratio of matrix phase from the slag with low basicity was only $13.0 \%$. When slag basicity increased, the dissolution ratio of matrix phase increased, but was not very 
large. In summary, selective leaching of the P-concentrated solid solution from steelmaking slag was achieved at $\mathrm{pH} 6$ in a wide range of slag compositions.

\section{Conclusions}

To clarify the applicability of this process to the steelmaking slags with various compositions, the effects of $\mathrm{P}_{2} \mathrm{O}_{5}$ content, $\mathrm{Fe}_{2} \mathrm{O}_{3}$ content, and slag basicity on the dissolution behavior of slags modified with the addition of $\mathrm{Na}_{2} \mathrm{O}$ were investigated in this study. The results obtained are summarized as follows:

(1) Increasing the $\mathrm{P}_{2} \mathrm{O}_{5}$ and $\mathrm{Fe}_{2} \mathrm{O}_{3}$ contents in slag resulted in a higher $\mathrm{P}_{2} \mathrm{O}_{5}$ content in the solid solution, while the mass fraction of solid solution decreased. With the increase in slag basicity, the $\mathrm{P}_{2} \mathrm{O}_{5}$ content in the solid solution decreased and the mass fraction of solid solution increased.

(2) The dissolution ratio of $\mathrm{P}$ reached approximately $76 \%$ regardless of the $\mathrm{P}_{2} \mathrm{O}_{5}$ content in slag, while the dissolution of $\mathrm{Fe}$ and $\mathrm{Mg}$ was slight. In the case of high $\mathrm{P}_{2} \mathrm{O}_{5}$ content, a leachate with higher $\mathrm{P}$ concentration and lower $\mathrm{Ca}$ and $\mathrm{Si}$ concentrations was obtained, exhibiting excellent selective leaching of $\mathrm{P}$.

(3) Increasing the $\mathrm{Fe}_{2} \mathrm{O}_{3}$ content in slag not only promoted dissolution of $\mathrm{P}$ but also decreased the dissolution ratios of other elements. With the increase in slag basicity, the dissolution ratios of $\mathrm{Ca}, \mathrm{Si}$, and $\mathrm{P}$ all increased.
(4) Most of the solid solution was dissolved from each slag without a large dissolution of other phases at $\mathrm{pH} 6$, indicating that selective leaching of solid solution was achieved in a wide range of slag compositions. After leaching, a residue with low $\mathrm{P}_{2} \mathrm{O}_{5}$ content and high $\mathrm{Fe}_{2} \mathrm{O}_{3}$ content was obtained.

\section{REFERENCES}

1) Production and Uses of Steel Slag in Japan, Nippon Slag Association, http://www.slg.jp/e/index.htm, (accessed 2017-10-09).

2) K. Yokoyama, H. Kubo, K. Nakajima and T. Nagasaka: J. Ind. Ecol., 13 (2009), 687.

3) K. Ito, M. Yanagisawa and N. Sano: Tetsu-to-Hagané, 68 (1982), 342.

4) H. Ono, A. Inagaki, T. Masui, H. Narita, T. Mitsuo, S. Nosaka and S. Gohda: Tetsu-to-Hagané, 66 (1980), 1317.

5) H.-J. Li, H. Suito and M. Tokuda: ISIJ Int., 35 (1995), 1079.

6) M. Ishikawa: ISIJ Int., 46 (2006), 530.

7) K. Yokoyama, H. Kubo, K. Mori, H. Okada, S. Takeuchi and T. Nagasaka: ISIJ Int., 47 (2007), 1541.

8) T. Miki and S. Kaneko: ISIJ Int., 55 (2015), 142.

9) T. Teratoko, N. Maruoka, H. Shibata and S. Kitamura: High Temp. Mater. Process., 31 (2012), 329.

10) C. Li, J. Gao and Z. Guo: ISIJ Int., 56 (2016), 759.

11) F. T. Nielsson: Manual of Fertilizer Processing, Marcel Dekker, New York, (1986), 147.

12) M. Numata, N. Maruoka, S. Kim and S. Kitamura: ISIJ Int., 54 (2014), 1983.

13) C. Du, X. Gao, S. Kim, S. Ueda and S. Kitamura: ISIJ Int., 56 (2016), 1436.

14) C. Du, X. Gao, S. Ueda and S. Kitamura: ISIJ Int., 57 (2017), 487.

15) C. Du, X. Gao, S. Ueda and S. Kitamura: J. Sustain. Metall., 3 (2017), 671.

16) S. Kitamura and F. Pahlevani: Tetsu-to-Hagané, 100 (2014), 500.

17) C. Du, X. Gao, S. Ueda and S. Kitamura: ISIJ Int., 58 (2018), 860.

18) K. Shimauchi, S. Kitamura and H. Shibata: ISIJ Int., 49 (2009), 505. 